\title{
Penatalaksanaan Akalasia Esophagus dengan Prosedur Pembedahan Heller Dilanjutkan Fundoplikasi
}

\author{
Management of Esophageal Achalasia with Heller Surgery Procedure Continued by Fundoplication
}

\author{
Nicko Rachmanio ${ }^{1 *}$, Guntur Surya Alam ${ }^{2}$ \\ ${ }^{1}$ Bagian IImu Bedah, Fakultas Kedokteran, Universitas Muhammadiyah Yogyakarta \\ 2 Bagian IImu Bedah Anak, RS DR. Moewardi, Surakarta
}

DATA OF ARTICLE:

Received: 07 Agust 2018

Reviewed: 6 Okt 2018

Revised: 12 Des 2018

Accepted: 10 Jan 2019

*CORRESPONDENCE:

nicko_rachmanio@yahoo.com

DOI:

10.18196/mm.190126

TYPE OF ARTICLE:

Case Report

\begin{abstract}
Abstrak: Akalasia esophagus merupakan gangguan motilitas esophagus berupa hilangnya gerakan peristaltik dan kegagalan relaksasi dari lower esophageal sphincter. Kasus ini tergolong jarang yaitu sebanyak 0,5-1,6\% dari seluruh populasi baik di Eropa, Asia, dan Amerika. Dilaporkan seorang anak laki-laki usia 14 bulan dengan keluhan sering muntah, berat badan kurang dan sulit naik. Pada pemeriksaan radiologis Oesophagus Maag Duodenum (OMD) ditemukan pelebaran oesophagus hingga gastrooesophageal junction. Dilakukan penatalaksanaan berupa pembedahan dengan prosedur Heller dilanjutkan dengan fundoplikasi. Pascaoperasi tidak ditemukan lagi keluhan pada pasien.
\end{abstract}

Kata kunci: Akalasia Esophagus; Myotomi Heller; Fundoplikasi

Abstract: Esophageal achalasia is a motility disorder of esophagus characterized by the absence of esophageal peristaltics and incomplete relaxation of lower esophageal sphincter. This case is rare, which is recorded as $0.5-1.6 \%$ of all population in Europe, Asia and America. A 14-month-old boy complaints of frequent vomiting, lack of weight and having difficulty to gain weight. The radiological examination of the Esophagus Maag Duodenum (OMD) discovered a dilatation of the esophageal to the gastroesophageal junction. Surgical treatment with the Heller's procedure is carried out followed by fundoplication. Postoperative complaints no longer found in patient.

Keywords: Esophageal Achalasia; Heller Myotomy; Fundoplication 


\section{PENDAHULUAN}

Akalasia esophagus adalah kelainan berupa ketidak mampuan relaksasi katup di daerah gastroesophageal junction sehingga makanan yang ditelan hanya sedikit yang dapat masuk ke dalam lambung. Angka kejadian sekitar 1/100.000 per tahunnya dan termasuk kasus yang sangat jarang terjadi. Sebanyak 0,5 - 1,6 \% ditemukan di Eropa, Asia, dan Amerika. ${ }^{1}$

Jumlah kasus yang sedikit menjadikan setiap penatalaksaan pasien dengan akalasia esophagus menjadi menarik untuk dipelajari. Laporan kasus ini menyajikan penatalaksanaan pasien akalasia esophagus yang meliputi penegakan diagnosis, tindak an operasi yang dilakukan sampai pada hasil yang didapatkan pasca operasi.

\section{LAPORAN KASUS}

Dilaporkan seorang anak usia 14 bulan, jenis kelamin laki-laki, sejak lahir ibu pasien mengeluhkan bahwa anaknya setiap kali diberi makan muntah, dan telah dibawa berobat ke dokter namun keluhan tidak juga berkurang. Berat badan pasien juga sulit naik. Riwayat kelahiran lahir spontan, bayi berat lahir cukup (BBLC) 3000 gr, cukup bulan, P1Ao. Pada pemeriksaan fisik tidak ditemukan kelainan pada pasien, kondisi pasien compos mentis (sadar penuh), bentuk kepala mesocephal, tidak didapatkan konjungtiva pucat, pemeriksaan jantung dan paru

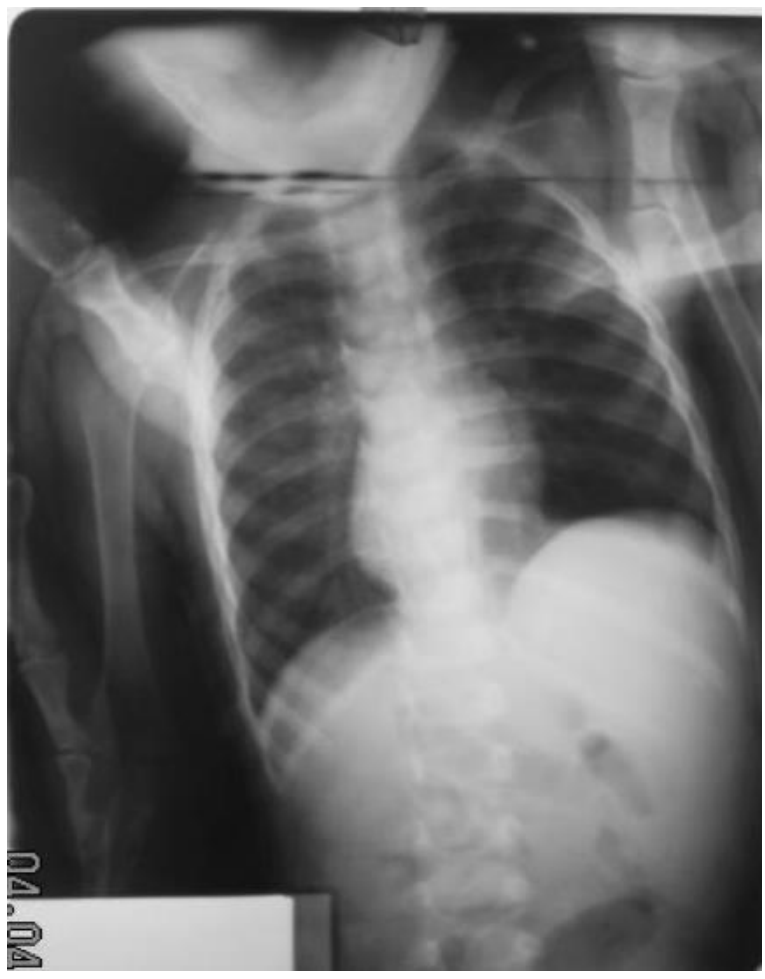

Gambar 1. Gambaran Rontgen Thoraks

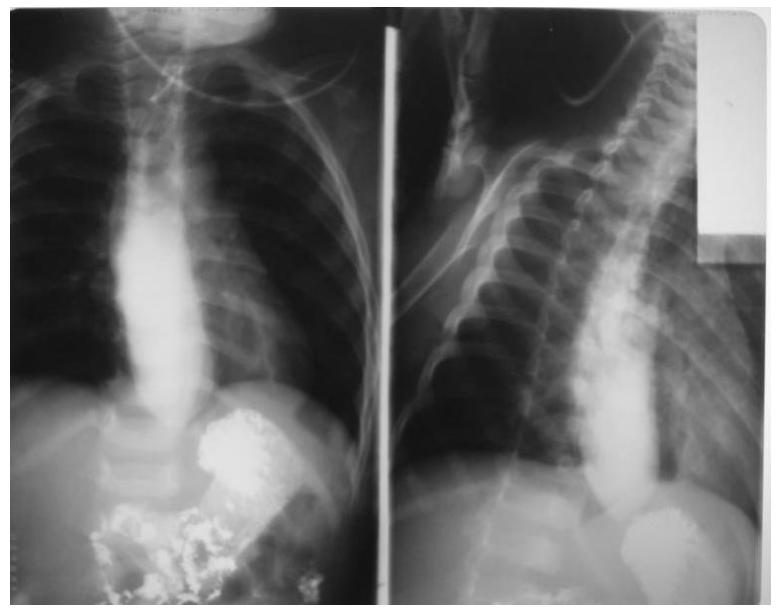

Gambar 2. Gambaran Rontgen Oesophagus Maag Duodenum (OMD)

normal, abdomen juga tidak didapatkan distensi, tidak teraba massa dan suara bising usus normal.

Pemeriksaan laboratorium darah pasien didapatkan masih dalam batas normal. Berikut hasil pemeriksaan darah rutin pasien dan nilai rujukan normal untuk usia pasien, kadar Haemoglobin: 10,5 gram/dL (10-17 gram/dL), Ht: 32,2 \% (31-45\%), Angka Leukosit: $14,700 \mathrm{sel} / \mathrm{mm}^{3}\left(5700-18.000 \mathrm{sel} / \mathrm{mm}^{3}\right)$, Angka Trombosit $360.000 \mathrm{sel} / \mathrm{mm}^{3} \quad$ (150.000$\left.450.000 \mathrm{sel} / \mathrm{mm}^{3}\right)$, Hitung Eritrosit 4,2 juta sel $/ \mathrm{mm}^{3}$ (3,8-6,1 juta sel/mm³).

Pada pasien kemudian dilakukan pemeriksaan radiologis rontgen thoraks dan Oesophagus Maag Duodenum (OMD), seperti terlihat pada Gambar 1. dan Gambar 2.

Pada Gambar 1. tidak ditemukan gambaran pneumonia pada paru pasien dan tidak didapatkan

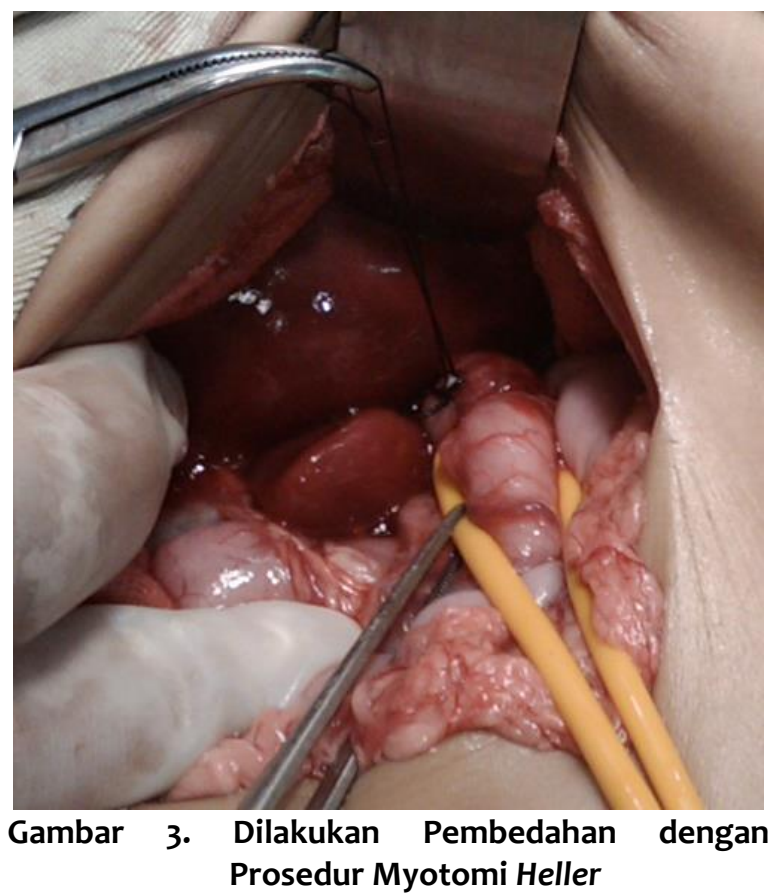




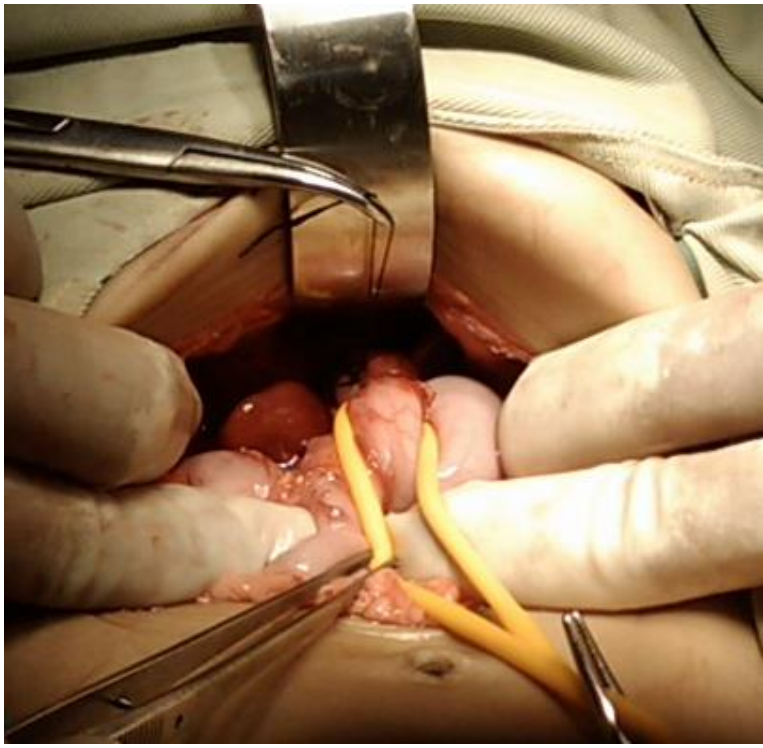

Gambar 4. Dilakukan Prosedur Fundoplikasi

gambaran udara bebas ataupun pelebaran dari mediastinum. Pada Gambar 2. terlihat gambaran oesophagus yang melebar dengan bagian distal menyempit, kontras dapat masuk hingga ke dalam lambung. Pada pasien kemudian dilakukan tindakan pembedahan dengan prosedur Heller dilanjutkan dengan Fundoplikasi seperti terlihat pada Gambar 3. dan Gambar 4.

Follow up pascaoperasi, pasien mulai diberikan diet cair satu hari pascaoperasi, vital sign stabil normal, tidak muntah, tidak ditemukan demam, nyeri dada, sesak, ataupun emphysema subkutis.

\section{DISKUSI}

Akalasia esophagus merupakan gangguan motilitas dari esophagus, ditandai dengan kegagalan peristaltik dan ketidakmampuan untuk relaksasi pada lower esophageal sphincter (LES). Beberapa peneliti berpikir bahwa akalasia berhubungan dengan infeksi virus. Penelitian terakhir menunjukkan akalasia disebabkan oleh sel saraf dari sistem saraf involunter pada lapisan otot pada esophagus yang dipengaruhi oleh sistem imun pasien sendiri dan secara perlahan mengalami degenerasi dengan alasan yang belum bisa dipahami. ${ }^{2}$

Akalasia dapat dikategorikan menjadi empat berdasarkan diameter dan panjang dari esophagus: Diameter $<4 \mathrm{~cm}$ adalah grade 1, Diameter $4-6 \mathrm{~cm}$ adalah grade 2, Diameter $>6 \mathrm{~cm}$ adalah grade 3 , dan grade 4 adalah suatu sigmoid oesophagus. ${ }^{3}$

Pada esophagus normal, gelombang peristaltik muncul setiap kali menelan, pada akalasia terdapat defek neuromuskular yang ditandai dengan menurunnya atau hilangnya peristaltik. Secara mikroskopik, terlihat adanya degenerasi dari sel ganglion pada pleksus myenterik Auerbach's. kondisi ini analog dengan megakolon. Pada keadaan normal terdapat zona oesophagus tekanan tinggi atau LES, pada akalasia, LES mengalami hipertonik, menghasilkan tekanan sisa menjadi di atas tekanan normal sehingga terjadi relaksasi inkomplit setelah menelan. Hal ini menyebabkan obstruksi fungsional dan menghasilkan pemanjangan serta pelebaran dari oesophagus dengan penyempitan pada bagian distal esophagus. Pada akalasia esophagus gejala dan tanda yang muncul dapat berupa: 1) Disfagia, merupakan gejala yang paling sering muncul, terutama pada saat menelan makanan padat dibandingkan dengan makanan lembut atau cairan. 2) Regurgitasi, muncul pada $95 \%$ pasien, beberapa pasien belajar untuk menghentikan untuk mengurangi nyeri yang ditimbulkan. 3) Nyeri pada dada, muncul pada $40 \%$ pasien, terutama setelah makan dan dirasakan seperti nyeri pada bagian retrosternal. Hal ini lebih sering dirasakan pada fase awal penyakit muncul. 4) Penurunan berat badan. 5) Batuk malam hari, jarang dan merupakan tanda dari suatu pneumonia inhalasi. ${ }^{4}$

Pemeriksaan penunjang radiologis yang sebaiknya dilakukan untuk mendiagnosis pasien dengan kecurigaan suatu akalasia esophagus diantaranya: 1) Foto polos dada: pada pemeriksaan ini mungkin dapat ditemukan tanda dari pneumonia inhalasi, dilatasi dari esophagus di belakang dari jantung (jarang terlihat pada kenyataannya), udara lambung biasanya terlihat sedikit atau kadang hilang. 2) Oesophagus maag duodenum (OMD) atau Esophagram: pada pemeriksaan ini dapat terlihat oesophagus yang dilatasi dan memanjang dengan gambaran "bird's beak" menyempit pada bagian kardia. Pemanjangan dan pelebaran esophagus menghasilkan kelengkungan yang nantinya menuju pada suatu sigmoid esophagus pada kasus yang ekstrem. 3) Esophagoscopy: pada pemeriksaan ditemukan sisa makanan pada esophagus yang melebar dengan disertai oesophagitis. LES ditemukan menyempit, namun esophaguscope dapat melalui dengan tekanan yang diperkirakan. Pemeriksaan ini seharusnya dilakukan karena dapat menyingkirkan diagnosis banding seperti karsinoma esophagus atau penyakit lainnya. 4) Esophageal manometry: merupakan suatu pelajaran penting dalam mendiagnosis akalasia, dapat menunjukkan absennya peristaltik pada esophagus serta tekanan tinggi pada LES yang mengalami kegagalan dalam relaksasi pada saat menelan. ${ }^{3}$

Penatalaksanaan pada pasien yang terdiagnosis suatu akalasia esophagus dapat dilakukan dengan tindakan: 1) Pelebaran dengan balon: balon dimasukkan ke dalam LES dengan endoscopy kemu- 


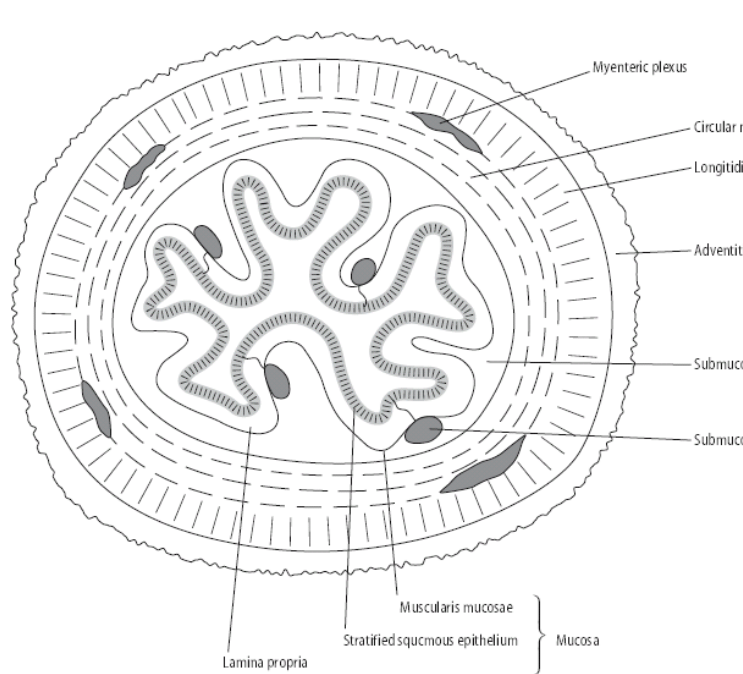

Gambar 5. Penampang Melintang dari Esophagus7

dian dikembangkan. Angka kesuksesan adalah 70$80 \%$ dengan $5 \%$ terjadi perforasi, apabila terjadi perforasi maka pembedahan emergensi harus dilakukan untuk menutup perforasi dan melakukan myotomi. Lebih dari separuh dari penderita memerlukan lebih dari satu kali pelebaran dengan balon. 2) Injeksi botulinum toksin: pada pasien yang tidak dapat dilakukan operasi dengan balon ataupun pembedahan dapat mengambil manfaat dari injeksi botulinum toksin. Pada saat diinjeksi dengan jumlah yang sedikit, botox dapat menyebabkan relaksasi dari spasme otot. Bekerja dengan cara mencegah saraf untuk melakukan hantaran ke otot untuk kontraksi. Presentasi kecil (35\%) dari pasien mendapatkan hasil jangka pendek yang baik dengan menggunakan botox. Sebagai tambahan, injeksi harus diulang beberapa kali dalam tujuan untuk mendapatkan hasil berupa bebas gejala. 3) Pembedahan: pembedahan dilakukan dengan Heller myotomi, pada operasi ini otot esophagus pada daerah katup antara esophagus dan lambung diinsisi hingga mencapai submukosa oesophagus. ${ }^{5}$

Komplikasi post operatif bisa terjadi obstruksi berkelanjutan, hal ini disebabkan oleh tidak efektifnya peristaltik pada akalasia esophagus yang panjang atau myotomi yang tidak komplit. Myotomi hingga dinding lambung dapat menyebabkan gastroesophagus reflux. Ahli bedah memiliki objektifitas untuk melakukan kombinasi Heller myotomi dengan fundoplikasi, dikarenakan meningkatnya tekanan di dalam lambung juga dapat menyebabkan tahanan untuk lewatnya isi oesophagus ke dalam lambung. ${ }^{6}$

Seorang penderita akalasia esophagus yang tidak ditangani ataupun yang sudah menjalani terapi bisa mendapatkan komplikasi seperti: 1) Akalasia yang tidak ditangani dapat menyebabkan inhalasi dari materi yang terjebak di esophagus serta aspirasi. 2) Penatalaksanaan dengan pembedahan dan dilatasi balon dapat menyebabkan perforasi dan gasstroesophagal reflux. 3) Karsinoma esophagus, antara $2-7 \%$ dari pasien mengalami karsinoma, penyakit dalam jangka panjang meningkatkan risiko. ${ }^{5}$

Berikut ini adalah follow up pasien akalasia esophagus pascaoperasi dengan prosedur Heller dan Fundoplikasi: 1) Pasien diberi diet oral dimulai dengan diet cair dan diet halus satu hari pascaoperasi apabila tidak ada keluhan mual. 2) Obat anti nyeri diberikan secara injeksi selama 6-12 jam post operatif, selanjutnya dapat menggunakan obat oral. 3) Dilakukan pengawasan klinis terjadinya leakage berupa perubahan vital sign yang mengarah ke sepsis, demam, kesulitan bernafas, nyeri dada, ataupun emphysema subkutan. 4) Apabila tanda klinis leakage tidak ditemukan, dilakukan pemeriksaan rontgen dengan kontras kontrol 6-7 hari post operatif. ${ }^{5}$

Yano dkk. (2014), ${ }^{8}$ melaporkan 400 kasus akalasia esophagus dalam kurun waktu antara tahun 1994 s.d tahun 2013 pada satu institusi yang sama dan dilakukan tindakan Heller Dor (Myotomi Heller dengan fundoplikasi), didapatkan hasil baik pasien dengan waktu operasi yang berbeda, jumlah kehilangan darah yang berbeda, waktu awal makan yang berbeda, keseluruhan menunjukkan bahwa prosedur operasi ini secara konstan memberikan hasil yang dapat diterima untuk memberikan kesembuhan pada pasien.

Caldaro dkk. (2015), ${ }^{9}$ membandingkan dua prosedur pembedahan untuk kasus akalasia esophagus yaitu dengan metode myotomi heller dan fundoplikasi secara laparoskopik dengan endoskopik peroral myotomi untuk mengevaluasi efektivitas, keamanan dan hasil dari kedua prosedur tersebut. Evaluasi didapatkan bahwa kedua prosedur memiliki hasil yang sama dan merupakan pilihan yang tepat untuk tatalaksana pasien dengan akalasia esophagus.

Illiceto dkk. (2016), ${ }^{10}$ melaporkan suatu laporan kasus seorang laki-laki usia 15 tahun dengan diagnosis akalasia esophagus yang dilakukan tindakan operasi myotomi heller diikuti dengan fundoplikasi menggunakan bantuan robot secara endoskopi. Follow up pascaoperasi terhadap pasien menunjukkan bahwa myotomi heller diikuti fundoplikasi merupakan pilihan untuk terapi akalasia esophagus. Kemajuan teknologi dengan pendekatan robotik secara endoskopi memberikan kemudahan bagi ahli bedah untuk melakukan prosedur ini.

Pada laporan kasus ini dilaporkan satu kasus, anak usia 14 bulan dengan keluhan muntah setiap 
habis makan dengan berat badan sulit naik. Dilakukan pemeriksaan dengan menggunakan kontras untuk melihat oesophagus dan lambung, ditemukan gambaran pelebaran diameter esophagus, dengan bagian distal menyempit namun kontras masih bisa masuk ke dalam lambung. Pada pasien dilakukan pembedahan myotomi prosedur Heller dilanjutkan fundoplikasi. Follow up pascaoperasi pasien diberikan diet oral, pasien tidak muntah, tanda vital stabil normal, tidak ada nyeri dada dan sesak, tidak ditemukan juga emphysema subkutis. Hal ini menunjukkan bahwa tidak terjadi leakage atau kebocoran pascaoperasi secara klinis.

\section{SIMPULAN}

Esophagus myotomi dengan prosedur Heller dilanjutkan dengan fundoplikasi merupakan tindakan pembedahan yang dapat dipilih untuk kasus akalasia esophagus.

\section{DAFTAR PUSTAKA}

1. Duffield JA, Hamer PW, Heddle R, Holloway RHh. Incidens of Achalasia in South Australia Based on Esophageal Manometry Findings. J Clin Gastroenterol Hepatol, 2017; 15 (3): 360-5.

2. Richter JE. Achalasia: An Update. J Neuroenterol Motil, 2001; 16 (3): 232-42.

3. Vanderpool D, Westmoreland MV, Fetner E. Achalasia: Willis or Heller? BUMC Proceedings, 1999; 12 (1): 227-230.
4. Ramirez M, Patti MG. Changes in the Diagnosis and Treatment of Achalasia. J Clin Transl Gastroenterol, 2015; 6 (5): e87.

5. Dobrowolsky A, Fisichella PM. 2014. The Management of Esophageal Achalasia: from Diagnosis to Surgical Treatment. J Gastrointestinal Surg, 2014; 66 (1): 23-9.

6. Rice TW, Mc Kelvey AA, Richter JE, Baker ME, Vaezi MF. A Physiologic Clinical Study of Achalasia: Should Dor Fundoplication be Added to Heller Myotomi?. J Thorac Cardiovasc Surg, 2005; 130 (6): 1593-600.

7. Aschraft KW. Atlas of Pediatric Surgery. Philadephia: W.B Saunders comp. 1994.

8. Yano F, Omura N, Tsuboi K, Hosino M, Yamamoto SR, Akimoto S, Masuda T, Kashiwagi $\mathrm{H}$, Yanaga K. The Outcomes of 400 Laparoscopic Heller's Dor Operation for Esophageal Achalasia. J Am Coll Surg, 2014; 219(4): 17.

9. Caldaro T, Familiari T, Romeo EF, Gigante G, Marchese M, Contini ACL, Abriola GF, Cucchiara S, Angelis P, Torroni F, Oglio L, Costamagna G. Treatment of Esopgaheal Achalasia in Children : Today and tomorrow. $J$ Pediatr Surg, 2015; 50 (5): 726-30.

10. Illiceto MT, Lisi G, Filippone M, Marino N, Chiessa PL, Lombardi G. Endoscopic Assisted Heller Extramucosal Myotomi with Antireflux Anterior Funduplication (DOR) in Robotic Approach for Esophageal Achalasia (EA). Digestive and Liver Dissease, 2016; 48 (4): e261-62. 